\title{
Stratigraphic position of alkaline volcanic rocks in the autochthonous cover of the High-Tatric Unit (Western Tatra Mts., Central Western Carpathians, Slovakia)
}

\author{
Jozef MADZIN ${ }^{1, *}$, Milan SÝKORA ${ }^{1}$ and Ján SOTÁK ${ }^{2}$ \\ 1 Department of Geology and Palaeontology, Faculty of Natural Sciences, Comenius University, Mlynská dolina G, 842 15, \\ Bratislava, Slovakia \\ 2 Geological Institute, Slovak Academy of Sciences, Severná 5, 974 01, Banská Bystrica, Slovakia
}

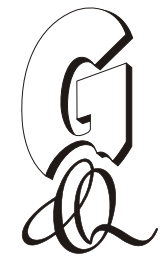

\begin{abstract}
Madzin J., Sýkora M. and Soták J. (2014) Stratigraphic position of alkaline volcanic rocks in the autochthonous cover of the High-Tatric Unit (Western Tatra Mts., Central Western Carpathians, Slovakia). Geological Quarterly, 58 (1): 163-180, doi: 10.7306/gq.1147

Biostratigraphic investigations of carbonate strata that sandwich volcanic rocks and studies of the volcanic rocks were made along five composite lithological sections across the Upper Jurassic-Lower Cretaceous carbonate rocks of autochthonous cover of the High-Tatric Unit in the Osobitá peak area of the Western Tatra Mts. A carbonate microbreccia that consists almost exclusively of limestone clasts containing calpionellids occurs immediately below the volcanics. The youngest identified microfossil Calpionella elliptica Cadisch in the individual limestone clasts showed the age of breccia formation to be younger than late Early-early Middle Berriasian. The volcanic rocks are overlain by the Osobitá Limestone Formation, which in the lowermost horizons consists of a few metres thick crinoidal limestone containing the foraminifers Meandrospira favrei (Charollais, Brönnimann and Zaninetti), Sabaudia minuta Hofker and Montsalevia salevensis (Charollais, Brönnimann and Zaninetti) indicating a Late Valanginian-Early Hauterivian age. The biostratigraphical and sedimentological data obtained show that volcanism took place in several phases. Less intense phases of volcanism are recorded as thin tuffitic laminae within the upper parts of the Tithonian-early Middle Berriasian Sobótka Limestone Member and as fragments of volcanic rock in the carbonate breccia. The main phase(s) of volcanism took place during the Late Berriasian-?Early Valanginian.
\end{abstract}

Key words: Central Western Carpathians, Western Tatra Mountains, autochthonous cover of the High-Tatric Unit, alkaline volcanism, biostratigraphy.

\section{INTRODUCTION}

The occurrence of Cretaceous volcanic rocks in the Western Carpathians is known from various tectonic units of both their central and external zones. The composition of these volcanic rocks corresponds to alkaline basalts/basanites (Hovorka and Spišiak, 1988; Spišiak and Hovorka, 1997). In the Central Western Carpathians, alkaline volcanic rocks are common though are not voluminous in Early to Mid-Cretaceous strata mainly from the Fatric, Tatric and probably also from the Hronic units (Hovorka and Spišiak, 1988). Volcanism is represented by small bodies of submarine lava with volcaniclastic rocks always associated with pelagic sediments and/or dykes and sills penetrating crystalline basement. The age of this volcanism based on biostratigraphic (Hovorka and Spišiak, 1988, 1993 and references therein) and geochronological data (K-Ar isotopic ages 106 and $116 \mathrm{Ma}$ according to Bujnovský et al., 1981 and approx. $100 \mathrm{Ma}$ according to Spišiak and Balogh, 2002) is generally Aptian to Early Albian.

\footnotetext{
* Corresponding author, e-mail: madzin@fns.uniba.sk
}

Received: December 3, 2012; accepted: December 16, 2013; first published online: January 4, 2014
Alkaline volcanic rocks in the autochthonous cover of the High-Tatric Unit from the Osobitá peak area in the Western Tatra Mts. (Fig. 1) have been studied since the end of the 19th century. Their petrography, petrology and geochemistry are comparatively well-known. Originally they were described as diabases (Uhlig, 1889) and later as limburgites and limburgite tuffs (Kreutz, 1909, 1913; Zorkovský, 1949). More recent studies, they have been interpreted as hyalobasanites and hyaloclastites (Hovorka and Spišiak, 1981, 1988, 1990, 1993; Spišiak and Hovorka, 1997; Hovorka et al., 1999; Ivan et al., 1999).

The age of volcanism from the Osobitá peak area is based only on biostratigraphic data obtained from the surrounding carbonate rocks. According by Kreutz (1909, 1913), volcanic activity took place during the latest Jurassic and earliest Cretaceous. Rabowski (1933) considered the volcanic activity to be probably younger than the Valanginian. A polyphase character of volcanism during the Tithonian to Early Berriasian was assumed by Kotański and Radwański (1959), the main phase being after the Early Berriasian (Staniszewska and Ciborowski, 2000).

The main purpose of this contribution is revision of the stratigraphic position of the alkaline volcanic rocks based on biostratigraphy and microfacies analysis of the underlying and overlying carbonate strata. The present study also attempts to clarify the palaeoenvironmental setting of the sedimentary processes and coeval volcanism. Possible volcanic processes that formed the volcaniclastic deposits are also discussed. 


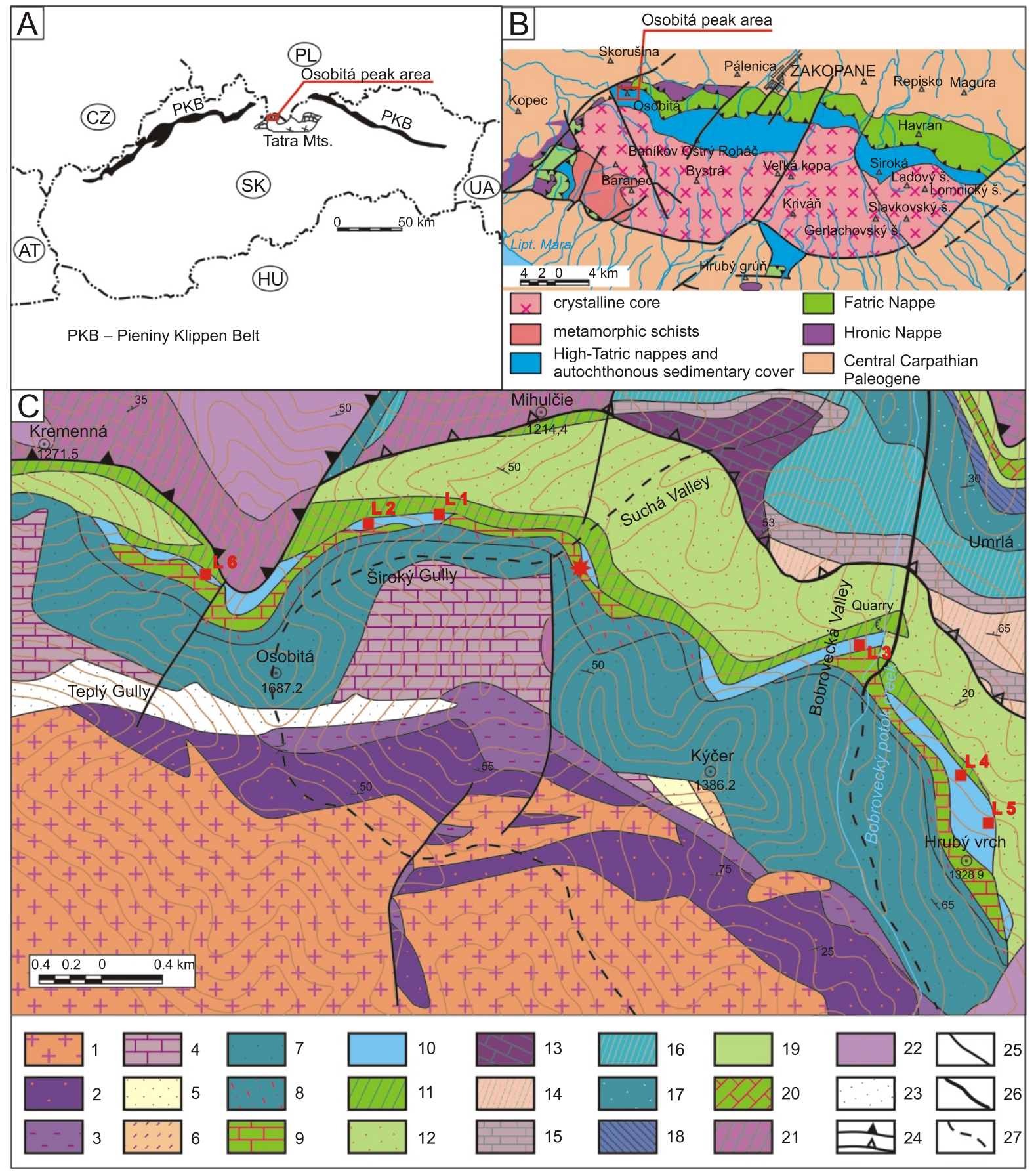

Fig. 1. Location and geological map of the Osobitá peak area with position of the sections studied (based on Lefeld et al., 1985 and Nemčok et al., 1993)

A - sketch-map with location of the Osobitá peak area; B - tectonic sketch of the Tatra Mts.; C - geological map of the study area with location of the sections studied; 1 - granitoid rocks of the crystalline basement; 2-12 High-Tatric Unit: 2 - Lúžna Fm. (Scythian), 3 - Werfenian beds (Scythian-Werfenian), 4 - Guttenstein Fm. (Anisian-Ladinian), 5 - Carpathian Keuper (Upper Carnian-Norian), 6 - Tomanová Fm. (Rhaetian), 7 - Trlenská Fm. (Hettangian-Bajocian), 8 - Vils Fm. (Bajocian-Bathonian), 9 - Raptawicka Turnia Limestone Fm. (Callovian-Hauterivian), 10 - Volcanic rocks (Upper Berriasian-Lower Valanginian), 11 Osobitá Limestone Fm. (Upper Valanginian-Lower Albian), 12 - Zabijak Marlstone Fm. (Albian-Lower Turonian); 13-20 Fatric Unit: 13 - Guttenstein Fm. (Anisian), 14 - Carpathian Keuper (Norian?-Lower Rhaetian), 15 - Fatra Fm. (Rhaetian),16 Kopienec Fm.(Hettangian-Sinemurian), 17 - Allgäu Fm. (Sinemurian-Lower Bajocian), 18 - Czorsztyn Limestone Fm. (Kimmeridgian-Lower Tithonian), 19 - Jasenina Fm. (Kimmeridgian?-Lower Berriasian), Osnica Fm. (Lower-Middle Berriasian), Kościeliska Marl Fm. (Upper Berriasian-?Lower Aptian), 20 - Muráň Limestone Fm. (Upper Hauterivian-?Lower Aptian); 21-22 Hronic Unit: 21 - Ramsau Dolomites (Anisian-Ladinian), 22 - Reifling Limestones (Upper Anisian-Ladinian); 23 - talus material; 24 - nappe décollement planes of the Fatric and Hronic Units; 25 - faults; 26 - roads; 27 - paths; L1-L6 - localities studied; red asterisk - exposure studied by Staniszewska and Ciborowski (2000) 


\section{GEOLOGICAL SETTING}

The Osobitá peak area studied is located in the western part of the Western Tatra Mts. In the Polish-Slovak borderland (Fig. 1). This area is built mostly of the Lower Triassic-Upper Cretaceous autochthonous sedimentary cover of the High-Tatric Unit. The High-Tatric Unit is overlain by the partial nappes of Fatric and Hronic units (Fig. 1). Stratigraphic research of the sedimentary succession of the Osobitá peak area has been performed mainly by Polish authors (Rabowski, 1933; Kotański and Radwański, 1959; Lefeld, 1968; Lefeld et al., 1985; Staniszewska and Ciborowski, 2000). The sedimentary succession of the Osobitá peak area includes unusual Upper Jurassic-Lower Cretaceous lithologies (Fig. 2) different from those of the other autochthonous sedimentary cover successions of the High-Tatric Unit in the Tatra Mts. The Upper Jurassic-Lower Cretaceous carbonate strata consist of the Raptawicka Turnia Limestone Formation that is represented by crinoidal and micritic limestones with thin tuffitic laminae of the Sobótka Limestone Member in this area (according to Lefeld et al., 1985). The Sobótka Limestone Member is about $20 \mathrm{~m}$ thick in the Osobitá peak area (Kotański and Radwański, 1959). In the Suchá Valley (asterisk on Fig. 1) in the uppermost part of the Sobótka Limestone Member, carbonate microbreccia has been reported (Staniszewska and Ciborowski, 2000). The breccia comprises exclusively limestone clasts, that are all similar to lithologies of the upper part of the Raptawicka Turnia Limestone Formation in the Polish part of the Western Tatra Mts. Based on calpionellid microfaunas in the individual limestone clasts, the formation of the breccia after the Early or Middle Berriasian was inferred (Staniszewska and Ciborowski, 2000). Volcanic rocks occur immediately above the carbonate microbreccia. They form very poorly exposed lenticular bodies and bands from the Predná Kremenná Valley through the Suchá Valley to the Bobrovecká Valley (Fig. 1). They are not resistant to weathering, and so are exposed almost exclusively as debris; contact with the carbonates has not been observed dirrectly, but it appears to be sharp. The true thickness of the volcanics is hence very hard to determine and estimates from two to thirty metres (Fig. 3). Nevertheless, small portions of subaqueous lavas with volcaniclastics have been described (Kreutz, 1913; Kotański and Radwański, 1959; Hovorka and Spišiak, 1981, 1988). One exposure of a $25 \mathrm{~m}$ thick lava body with tuffitic conglomerates was reported by Kotański and Radwański (1959) on the east slope of Osobitá peak.

The volcanic rocks are overlain by the $45-60 \mathrm{~m}$ thick Osobitá Limestone Formation of Barremian-Lower Aptian age, which represents a distal facies of the High-Tatric "Urgonian" (Lefeld, 1968; Lefeld et al., 1985). The Osobitá Limestone Formation consists of dark grey, almost black, well-bedded fine organodetrital limestones with brownish cherts. Very thin strata of dark grey pelitic limestone with globigerinas have been described at the base of the Osobitá Limestone Formation; they are followed by dark and reddish crinoidal limestones a few metres thick with small brachiopods, bivalves, orbitolinas and belemnoids (Lefeld, 1968; Lefeld et al., 1985). The lower boundary of the Osobitá Limestone Formation is characterized as a tectonic contact against volcanic rocks, and so the lowest horizons of this formation are missing in places (Lefeld et al., 1985). The sedimentary sequence of the High-Tatric Unit in the Osobitá peak area is terminated by the Albian-Lower Turonian Zabijak Marlstone Formation (Krajewski, 1981).

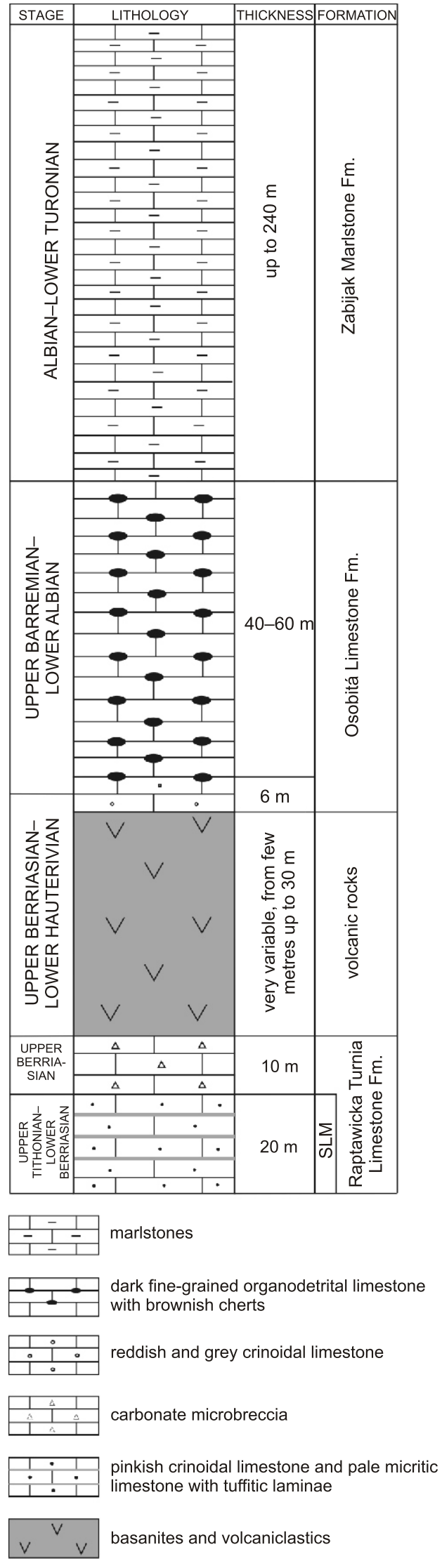

SLM - Sobótka Limestone Member

Fig. 2. Lithological column of the Upper Jurassic-Cretaceous deposits of the sedimentary succession of the Osobitá peak area (modified after Lefeld et al., 1985; Staniszewska and Ciborowski, 2000 and our research) 


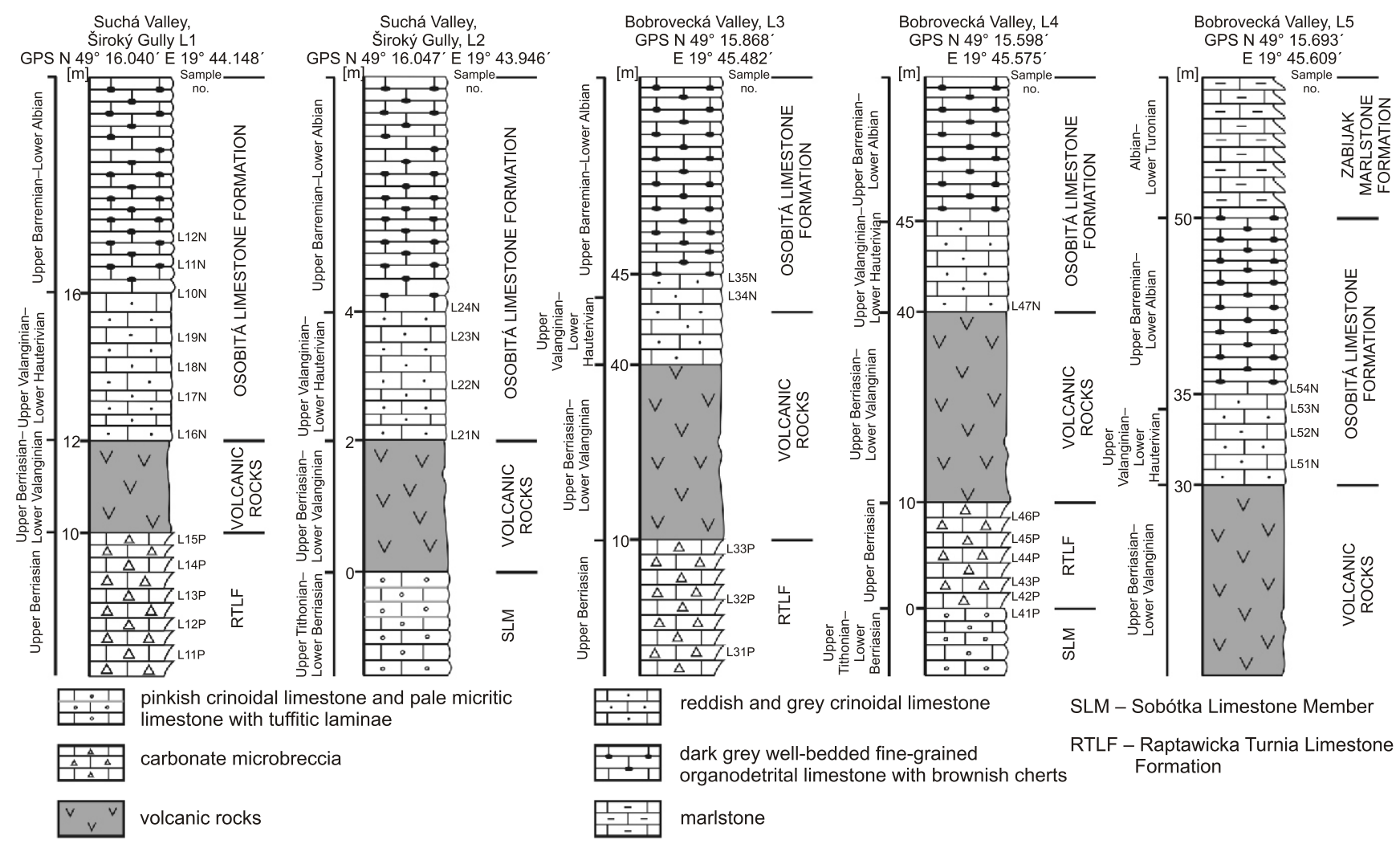

Fig. 3. Composite lithological sections from the Osobitá peak area

For location see Figure 1

MATERIAL AND METHODS

The work described is based mainly on biostratigraphic and microfacies analysis of the uppermost Jurassic-lowermost Cretaceous carbonate strata sandwiching the bodies of volcanic rock. Detailed field observations of the relationships between the host carbonate deposits and the volcanic rocks have been obtained from five composite sections (Fig. 3) in the Suchá Valley: L1, L2 - a hunting path at the northern edge of the Široký Gully; in the Bobrovecká Valley: L3 - on the western slope ca. $100 \mathrm{~m}$ south of an old quarry, L4 - a hunting path on the eastern slope, L5 - ca. $200 \mathrm{~m}$ above the hunting path; and one locality in the Predná Kremenná Valley: L6 - the northwestern slope of Osobitá peak (Fig. 1), where samples of volcanic rocks were collected from debris. Observations focused on the character of the contacts of the volcanic rocks with the underand overlying carbonates, and on detailed sampling. In each section, samples both from under- and overlying carbonate beds were taken from the closest contact with volcanic rocks. Then, the sections were analysed bed-by-bed via detailed sampling (Fig. 3). The microfacies of the carbonate rocks were analysed in 43 thin sections. Microfacies analysis follows the classification by Dunham (1962). The biostratigraphy of the Tithonian-Berriasian limestones studied is based on the calpionellid zonation by Reháková and Michalík (1997).

Description of the volcaniclastic deposits follows Fisher (1961), Fisher and Schmincke (1984), McPhie et al. (1993) and White and Houghton (2006).

\section{RESULTS}

LIMESTONES UNDERLYING THE VOLCANIC ROCKS

The oldest rocks sampled in the sections studied are light pink crinoidal limestones (L2, L4, Fig. 3), included here in the Sobótka Limestone Member. The Sobótka Limestone Member is characterized by alternating greyish-pinkish crinoidal limestone and pale micritic limestone with calpionellids. It contains in its upper part thin tuffitic laminae associated with the overlying volcanic rocks (Lefeld et al., 1985). The crinoidal limestones sampled represent well-sorted grainstones that contain almost exclusively fragments of crinoids with a detrital admixture (sample L41P) consisting of rounded quartz and K-feldspar grains up to $2 \mathrm{~mm}$ across and clays. No index microfauna was observed in the thin sections.

At the exposure by Staniszewska and Ciborowski (2000) in the Suchá Valley (asterisk on Fig. 1) the $10 \mathrm{~m}$ thick carbonate breccia occurs between underlying crinoidal limestones of the Sobótka Limestone Member and overlying volcanic rocks. The same situation is present at localities studied by us (Fig. 3). The breccia is about $10 \mathrm{~m}$ thick and occurs immediately below the volcanic rocks. The breccia contains three main types of limestone clast, the same as those described by Staniszewska and Ciborowski (2000): organodetrital limestone, oolitic limestone and micritic limestone. The limestone clasts are angular, subangular and subrounded in shape and are very poorly sorted. They range from 0.3 to $8 \mathrm{~mm}$ across. Clast margins without sharp contacts with the surrounding matrix are quite 

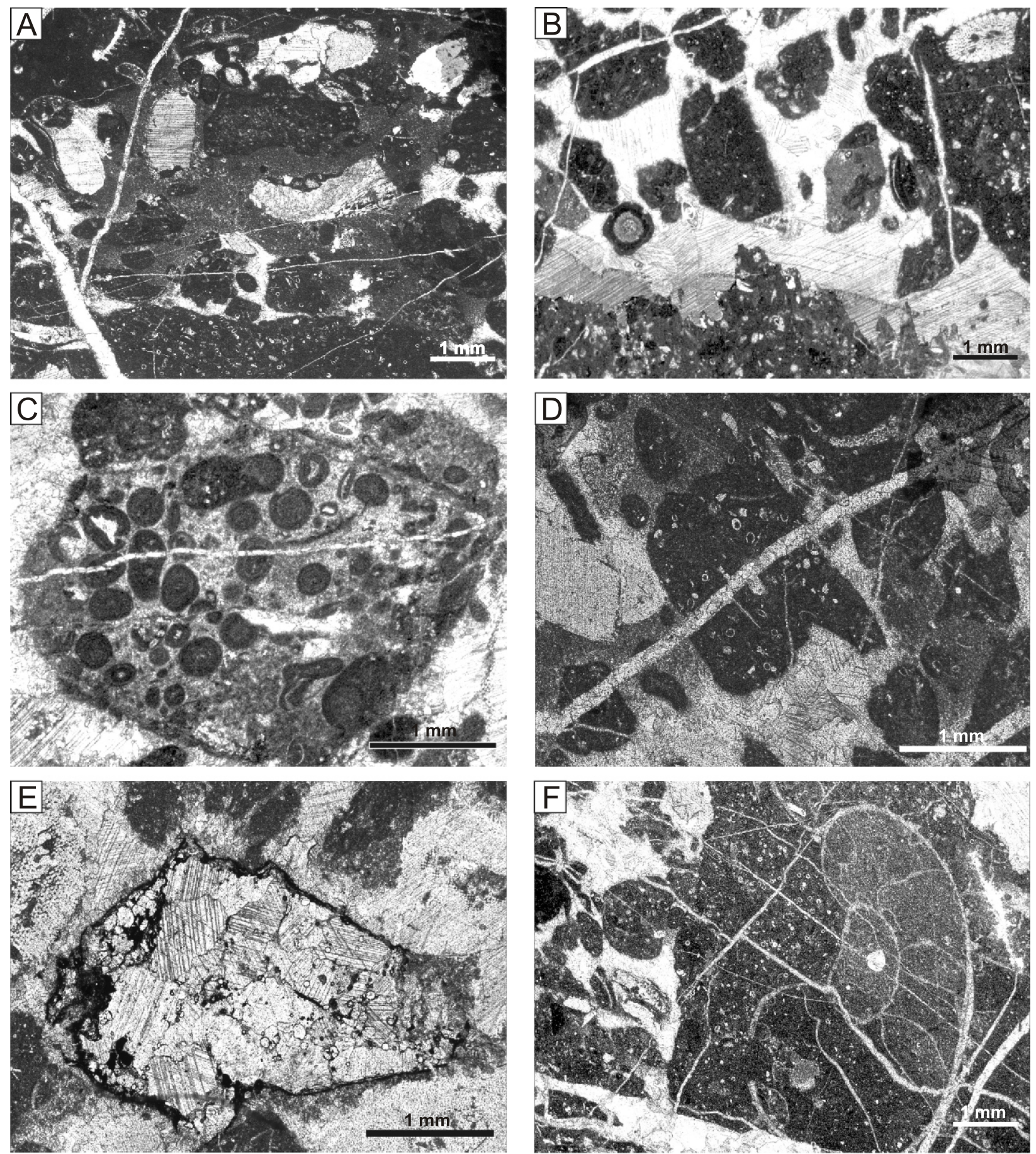

Fig. 4. Microfacies of limestones underlying the volcanic rocks

A - carbonate microbreccia, matrix is composed of micrite, (XPL - cross polarized light), sample L14P; B - carbonate microbreccia cemented by sparite, (XPL), sample L33P; C - clast of oolitic limestone, (XPL), sample L15P; D - clast of micritic limestone, (XPL), sample L14P; E - fragment of totally pseudomorphed volcanic rock, (XPL), sample L15P; F - clast of organodetrital limestone, (XPL), sample L14P

common. A few clasts consist of smaller clasts of the same type, formed by repeated redeposition. Apart from clasts of limestone, the breccia contains also scattered completely pseudomorphed fragments of volcanic rock (Fig. 4E), occasionally also clays. The matrix of the breccia is mainly composed of micrite, but locally also includes sparite (Fig. 4A, B). Organic detritus in the matrix of breccia is represented by fragments of crinoids, echinoids, hyaline foraminifers such as Lenticulina sp., bryozoa, fish bone fragments, brachiopods and molluscs.
ORGANODETRITAL LIMESTONE LITHOCLASTS

The organodetrital limestones are bioturbated wackestones/packstones with abundant organic detritus. A Globochaete-Saccocoma microfacies is characteristic. Calcified sponge spicules, fragments of crinoid, radiolarians, echinoid spines, ostracods and juvenile ammonites (Fig. 4F) are also present. Rare undetermined agglutinated foraminifers and the hyaline foraminifer Lenticulina sp. also occur. The organodetrital limestone, in addition to the microfauna de- 

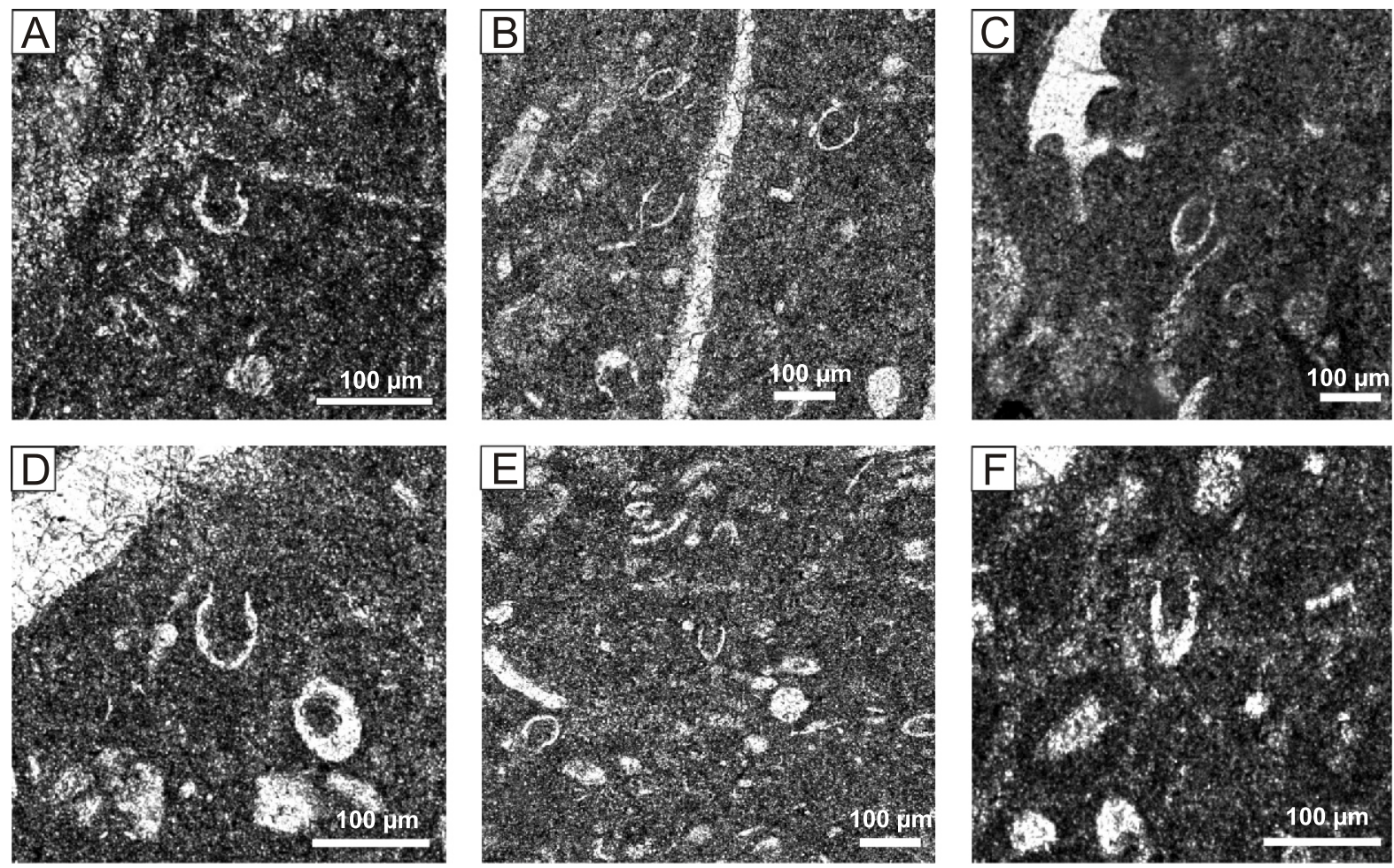

Fig. 5. Calpionellids from carbonate microbreccia (samples L14P and L15P)

A - Calpionella minuta (Houša); B - Tintinopsella carpathica (Murgeanu and Filipescu) (left), Calpionella alpina Lorenz (right); C Calpionella elliptica Cadisch; D - Calpionella grandalpina Nagy; E - Crassicollaria brevis (Remane); F - Crassicollaria parvula Remane

scribed above, also contains the calcareous dinoflagellate Cadosina semiradiata Wanner, the cyst Shizopherella minuttissima Colom and callpionellids, such as Crassicollaria sp., Calpionella alpina Lorenz and Calpionella elliptica Cadisch (Fig. 5). This calpionellid assemblage corresponds to the Elliptica Subzone of the Calpionella Zone of the late Early and early Middle Berriasian.

\section{OOLITIC LIMESTONE LITHOCLASTS}

The oolitic limestones contain micritic ooids of regular shape and size about $0.30 \mathrm{~mm}$ across occurring in a micritic and/or spary matrix (Fig. 4C). Ooids of the same size also occur in the matrix of the breccia. The nuclei of the ooids contain mostly the planktonic crinoid Saccocoma and a calpionellid association of Crassicollaria parvula Remane, Crassicollaria massutiana (Colom), Crassicollaria brevis Remane, Crassicollaria colomi Doben, Calpionella alpina Lorenz and Calpionella grandalpina Nagy (Fig. 5D). This calpionellid association corresponds to the Crassicollaria Zone up to the Alpina Zone of the Calpionella Zone of the Late Tithonian and Early Berriasian.

MICRITIC LIMESTONE LITHOCLASTS

The micritic limestones are represented by mudstones and wackestones which contain a predominantly calpionellid microfauna (Fig. 4D). Calpionella alpina Lorenz, Calpionella elliptica Cadisch and Calpionella minuta Houša are most frequent. Rare Tintinopsella carpathica (Murgeanu and Filipescu) also occurs (Fig. 5B). This calpionellid association indicates the Elliptica Subzone of the Calpionella Zone of the late Early and early Mid- dle Berriasian. The micritic limestones also contain calcified sponge spicules, echinoderm fragments, ostracods, aptychi and juvenile ammonites.

\section{VOLCANIC ROCKS}

Volcanic rocks occur in normal stratigraphic position sandwiched between the underlying carbonate microbreccia and overlying Osobitá Limestone Formation. Volcanics are not resistant to weathering, and consequently occur only as debris. Direct exposures have not been documented during our research. Moreover, the volcanic rocks are extensively altered; therefore, rarely fresh samples are preserved. They occur as two different volcanic lithofacies: volcaniclastics and rocks of coherent lavas.

\section{VOLCANICLASTICS}

The prevalent volcanic rocks are volcaniclastics (Fisher, 1961; Figs. 6 and 7). These contain evident features of either a sedimentary (syn- or post-eruption reworking and redeposition) or pyroclastic density current origin (see discussion below). Therefore, we use the classification and terminology for the description of volcaniclastic rocks suggested by White and Houghton (2006) which can be used for volcaniclastic deposits of uncertain or ambiguous origin.

Two principal volcaniclastic lithofacies, defined by grain-size, sorting and sedimentary features (gradation, lamination) are recognized. The first type is composed of mostly poorly sorted subangular blocky and splinter-shaped shards of highly altered and occasionally fresh basanites and basanite glass 

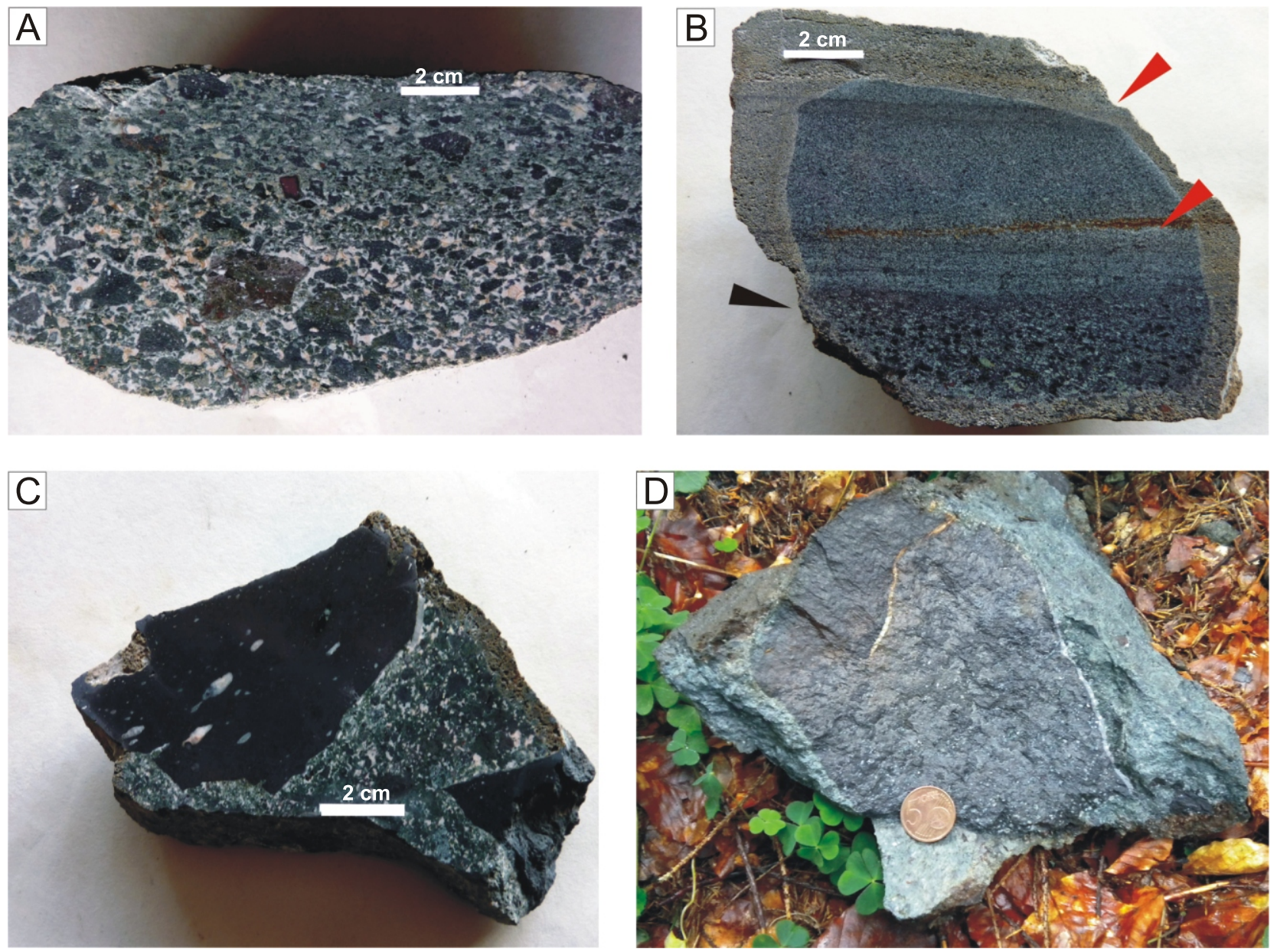

Fig. 6. Volcaniclastics

A - poorly sorted lapilli tuff (hyaloclastite), locality L3; B - gradation (black arrow) and parallel lamination (red arrow) in coarse ash to fine lapilli tuff, locality L1; C, D - subangular to angular blocks of basanite in fine to coarse lapilli tuff, locality L4

(Figs. 6A and 7A, B). Shards size varies from very coarse ash to coarse lapilli, but lapilli-sized volcaniclastics predominate. The shards are dense to moderately vesicular, but rare highly vesicular shards also occur. Shard margins commonly have developed thin rims of hydrothermally altered minerals (most probably albite and chlorite) and undefined zeolite minerals (Fig. 7D). Subangular to subrounded blocks (>64 to $200 \mathrm{~mm}$ ) of fresh dark grey and black grey basanites overlain by coarse lapilli tuff also occur (locality L4, Fig. 6C, D). These volcaniclastic rocks are both clast- and matrix-supported. Their matrix is composed mainly of carbonate, often coloured by finely dispersed hematite (Fig. 7A, C).

The second volcaniclastic type was found at localies L1 and L2 (Suchá Valley, Široký Gully). This comprises fine ash- to fine lapilli-sized fragments of basanite, of subangular to angular shape. Volcaniclastics of this type contain a lithic admixture $(<5 \%)$ of scattered subangular quartz grains with undulatory extinction, fragments of crinoids, clasts of carbonates and minerals of the spinel group ( $\mathrm{Fe}-\mathrm{Ti}$ spinels-titanomagnetites, according to Mikuš et al., 2006; Fig. 7E, F). These rocks are moderately to well-sorted and exhibit clear sedimentary features, such as parallel lamination and grading (Fig. 6B). The matrix is composed of carbonate (Fig. 7E, F).

\section{ROCKS OF COHERENT LAVA FLOWS-BASANITES}

Rocks of coherent lava bodies - basanites or hyalobasanites - were found only as debris at locality L6 in the Predná Kremenná Valley (Fig. 1); consequently, their description is based mostly upon the investigations of Hovorka and Spišiak (1981, 1988). Dark grey and almost black hyalobasanites with amygdaloidal texture are most frequent. Amygdales range from $1 \mathrm{~mm}$ to $1.5 \mathrm{~cm}$ across and exhibit a characteristic elongated shape (Fig. 8A, B). They are filled in with secondary minerals such as calcite, epidote, chlorite, hematite, albite and zeolite (Fig. 8D; Hovorka and Spišiak, 1988). The hyalobasanites have a fine-grained hemicrystalline matrix composed of devitrified volcanic glass (Fig. 8C, D). Olivines and pyroxenes form phenocrysts; locally, glomerophyric accumulations of these phases are present (Hovorka and Spišiak, 1981). Phenocrysts of idiomorphic olivines (Fig. 8C) and pyroxenes (Ti-augites) are completely replaced by chlorite and/or carbonate and only pseudomorphs can be observed. Phenocrysts are preferentially oriented in places (see Hovorka and Spišiak, 1988: table XII, fig. 1). Accessory minerals are represented by apatite and ilmenite (Hovorka and Spišiak, 1981, 1988). The hyalobasanites contain also small (sand-sized) scattered xenoliths of recrystallised carbonates (Hovorka and Spišiak, 1981). 

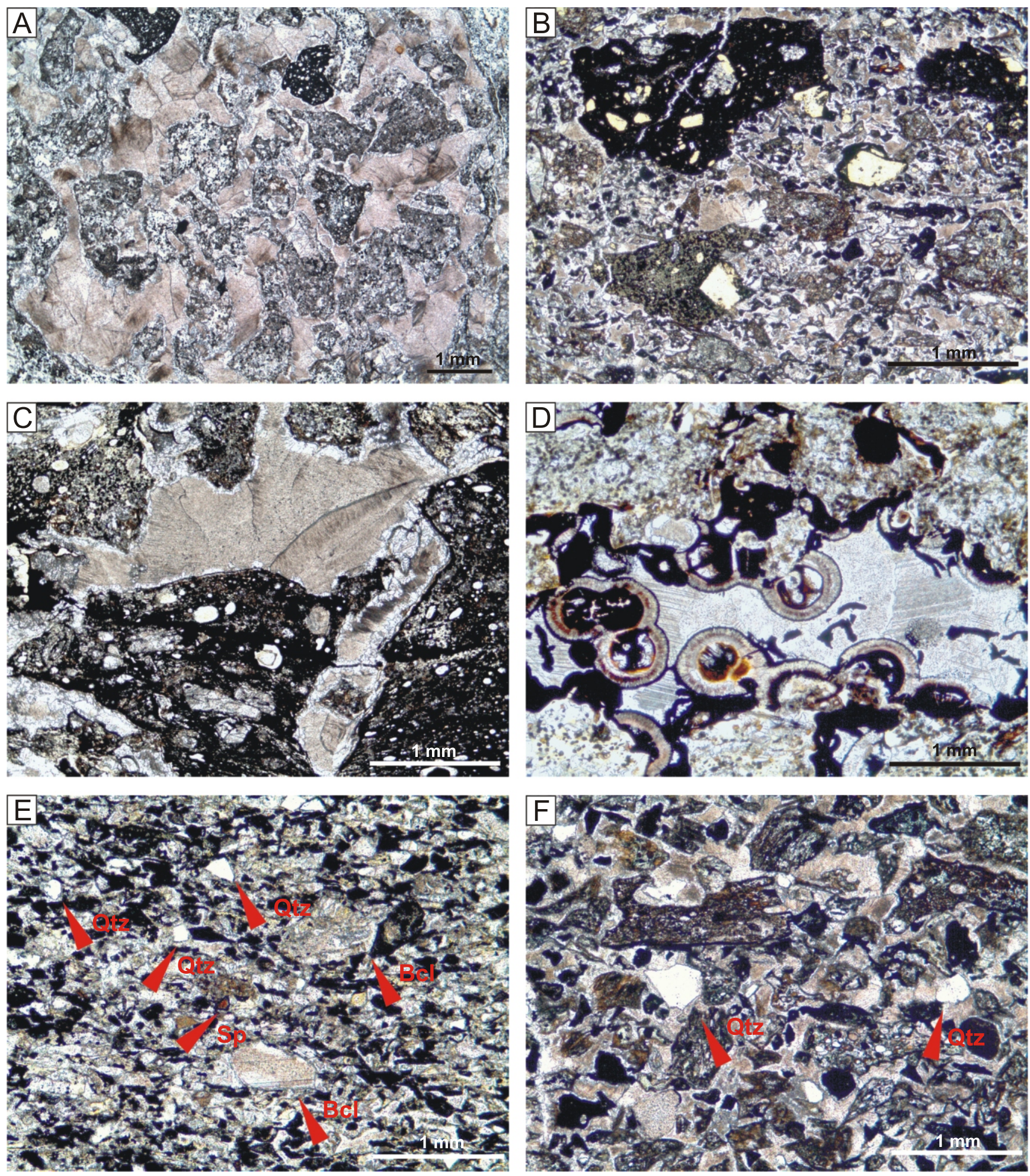

Fig. 7. Microscopic features of the volcaniclastic rocks

A - hyaloclastite composed of relatively well-sorted blocky highly altered shards of basanite, (XPL), locality L3; B - poorly sorted hyaloclastite - relatively fresh shards of basanite also occur, (XPL), locality L3; C - matrix of hyaloclastite is composed of carbonate, (XPL), locality L3; D - alteration of basanite shards, black hematite rims and undefined zeolite minerals, (XPL), locality L3; E - non-volcanic admixture of angular to subangular quartz grains (Qtz), a mineral of the spinel group (Sp) and crinoid fragments (Bcl) in fine tuff (XPL), locality $L 1 ; \mathbf{F}$ - unabraded shape of basanite shards and non-volcanic admixture of angular to subangular quartz grains in coarse ash to fine lapilli tuff, $(\mathrm{XPL})$, locality L1 

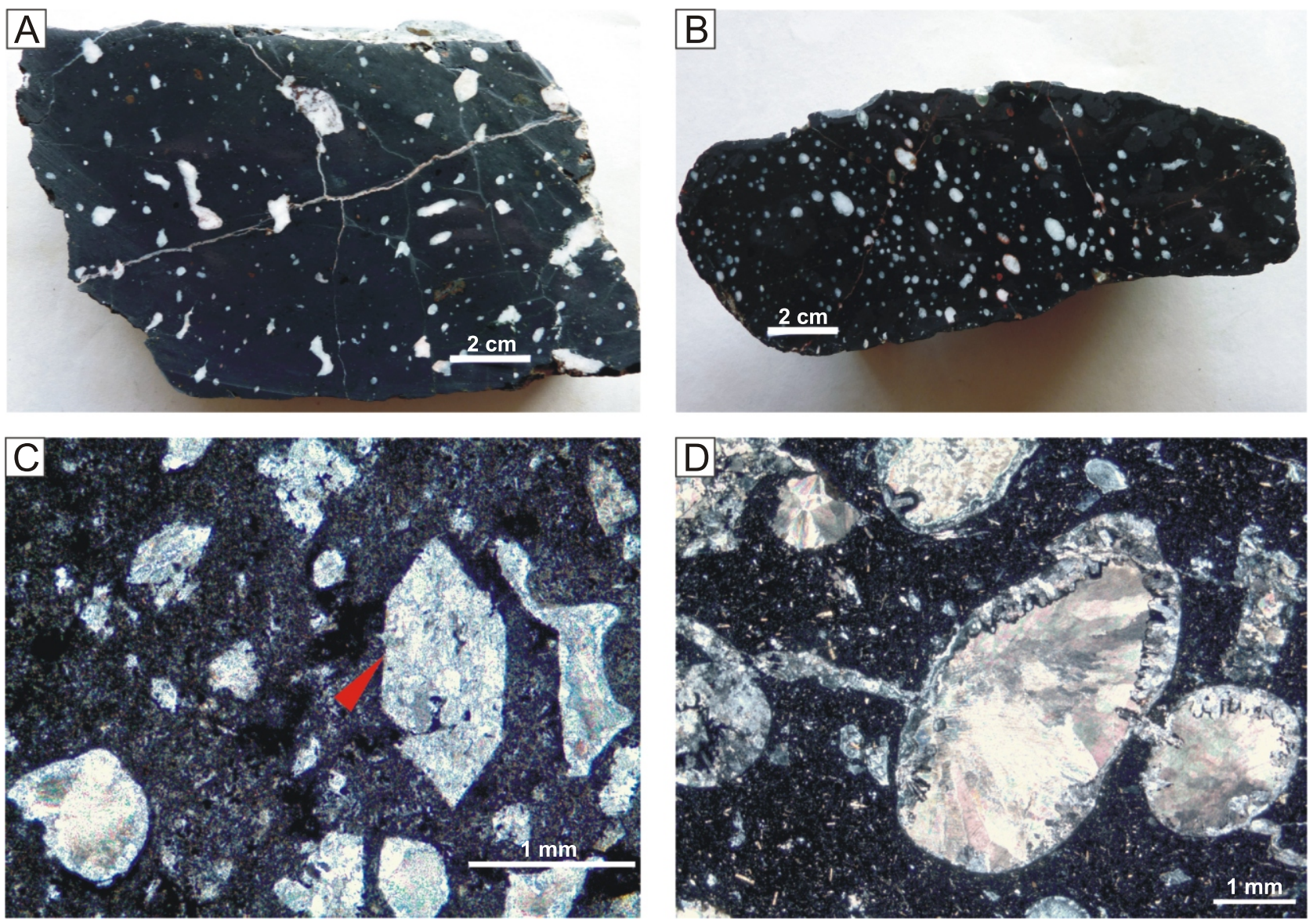

Fig. 8. Rocks of coherent lavas - basanites

A, B - basanite with elongate amygdales showing preferred orientation, locality L6; C - idiomorphic completely pseudomorphed olivine (arrow) (XPL), D - amygdales in hyalobasanite filled with carbonate, while rims consist of albite and chlorite, (XPL)

LIMESTONES OVERLYING THE VOLCANIC ROCKS

The volcanic rocks are covered by reddish and dark grey organodetrital crinoidal limestones 4-6 m thick (Fig. 9A) at all localities studied. In their lowermost levels coarse-grained grainstones and grainstones/packstones occur (Fig. 9B-D). Fine-grained packstones/wackestones dominate in the higher parts of the crinoidal limestone sequence. The crinoidal limestones are followed by dark grey well-bedded cherty fine-grained organodetrital limestones (Fig. 3), both together forming the 45-60 m thick Osobitá Limestone Formation (Lefeld, 1968; Lefeld et al., 1985). The crinoidal limestones contain abundant fragments of crinoid, bivalve and brachiopod shells, bryozoa, fish bone fragments, the hyaline foraminifer Lenticulina sp., worm tubes, algae and echinoid spines. Fragments of belemnite rostra and coral (Fig. 9E) were also observed. Sporadically, intraclasts of organodetrital limestones identical to those which form the carbonate microbreccia underlying the volcanic rocks are present (Fig. 9C). The intraclasts are subangular, poorly sorted and contain sponge spicules, radiolarians, echinoid spines, ostracods and calpionellids such as Crassicollaria sp. and Calpionella alpina Lorenz. Rare clasts of totally pseudomorphed volcanic rock (Fig. 9F), minerals of the spinel group, subangular to subrounded quartz grains (Fig. 9C, D) and K-feldspar grains also occur.
The crinoidal limestones in the lower part of the sections studied contain associations of orbitolinid, meandrospiroid and verneulid foraminifers (Fig. 10) such as Meandrospira favrei (Charollais, Brönnimann and Zaninetti), Sabaudia minuta Hofker, Montsalevia salevensis (Charollais, Brönnimann and Zaninetti) determinating the Late Valanginian-Early Hauterivian age of this lowermost horizon of the Osobitá Limestone Formation. This association of foraminifers is accompanied by Bolivinopsis ammovitrea (Tappan), Dorothia praeoxycona Moullade, Pseudomarsonella cf. bipartita Redmond, Belorusiella textilarioides (Reuss), Verneuilina cf. pharaonica Said, Arenobulimina cf. corniculum ArnaudVanneau, Vercorsella scarsellai (De Castro), Siphovalvulina $s p$., Patellovalvulina sp. and the rare planktonic foraminifer Hedbergella infracretacea (Glaessner).

At localities L3 and L5 in the Bobrovecká Valley, the samples L34N, L35N and L52N, L53N (Fig. 3) from higher levels of the crinoidal limestone contain orbitolinid foraminifers. The diagnostic embryonic apparatus is not visible but the material strongly resembles Mesorbitolina texana (Roemer; Fig. 10G). Consequently, we describe this only as orbitolinid foraminifers of the Palorbitolina-Mesorbitolina group of wider stratigraphic range. Orbitolinas of this group indicate a Late Barremian up to Early Albian age for these crinoidal limestones. 

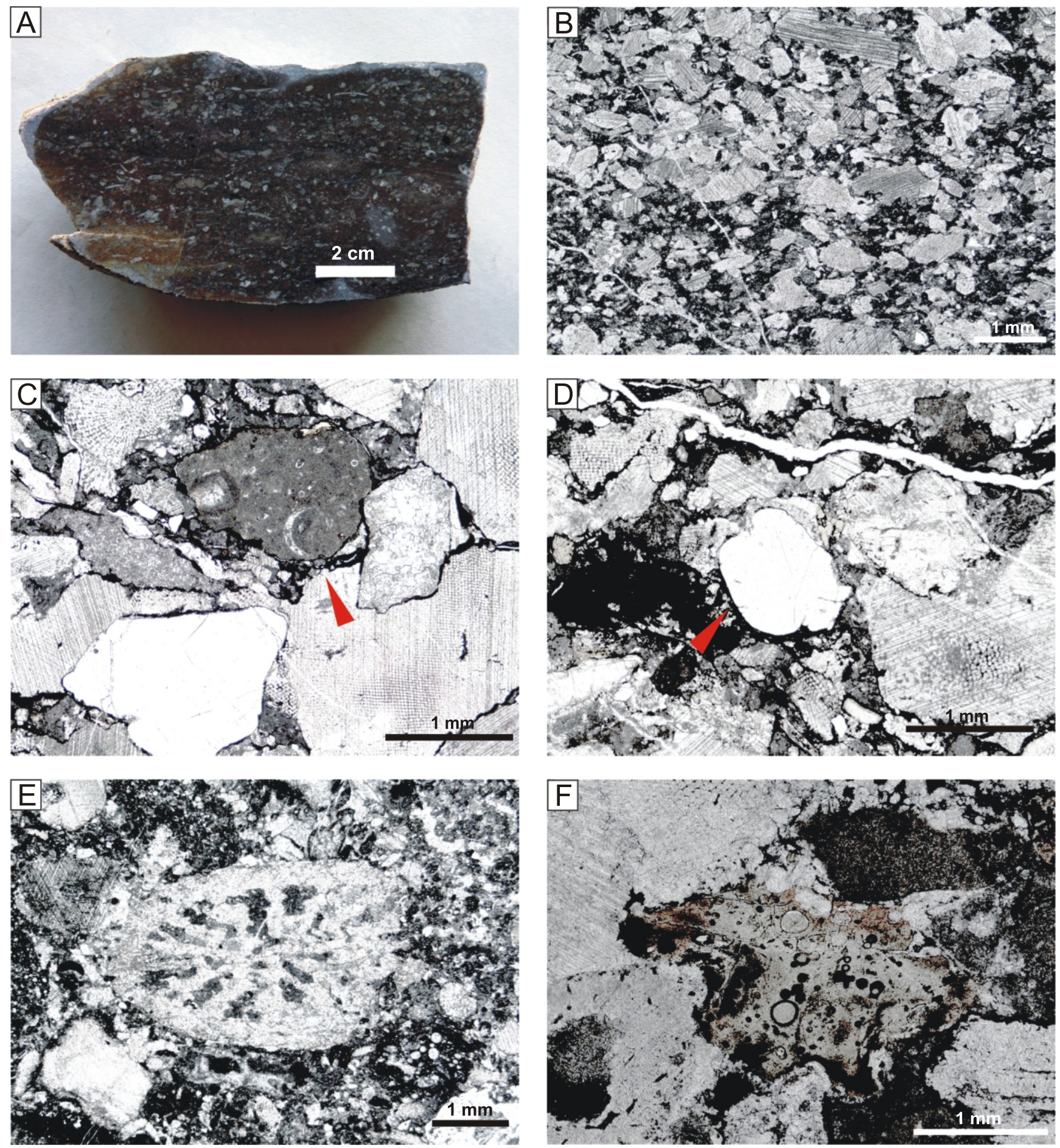

Fig. 9. Microfacies of limestones overlying the volcanic rocks

A - crinoidal limestone from the lowermost part of the Osobitá Limestone Formation, sample L16N; B - crinoidal packstone/grainstone, (XPL), sample L22N; C - intraclast of organodetrital limestone (arrowed) with calpionellids in the crinoidal packstone/grainstone, (XPL), sample L16N; D - subrounded quartz grain (arrowed) in the crinoidal packstone/grainstone, (XPL), sample L16N; E - coral skeleton in crinoidal packstone, (XPL), sample L52N; F - fragment of volcanic rock in crinoidal packstone/grainstone, sample L16N (XPL)

Fig. 10. Foraminifer association in the crinoidal limestones immediately overlying the volcanic rocks

A - Sabaudia minuta Hofker, sample L17N; B, C - Montsalevia salevensis (Charolais, Brönnimann and Zaninetti), sample L17N; D, E Meandrospira favrei (Charolais, Brönnimann and Zaninetti), sample L17N; F - Bolivinopsis ammovitrea (Tappan), sample L22N; G orbitolinid foraminifer of the Palorbitolina-Mesorbitolina group, sample L34N; H - Verneuilina cf. pharaonica Said, sample L17N; I Belorusiella textilarioides (Reuss), sample L17N; J - Dorothia praeoxycona Moullade, sample L16N; K - Pseudomarsonella cf. bipartita Redmond, sample L16N; L - planktonic foraminifer Hedbergella infracretacea (Glaessner), sample L17N 

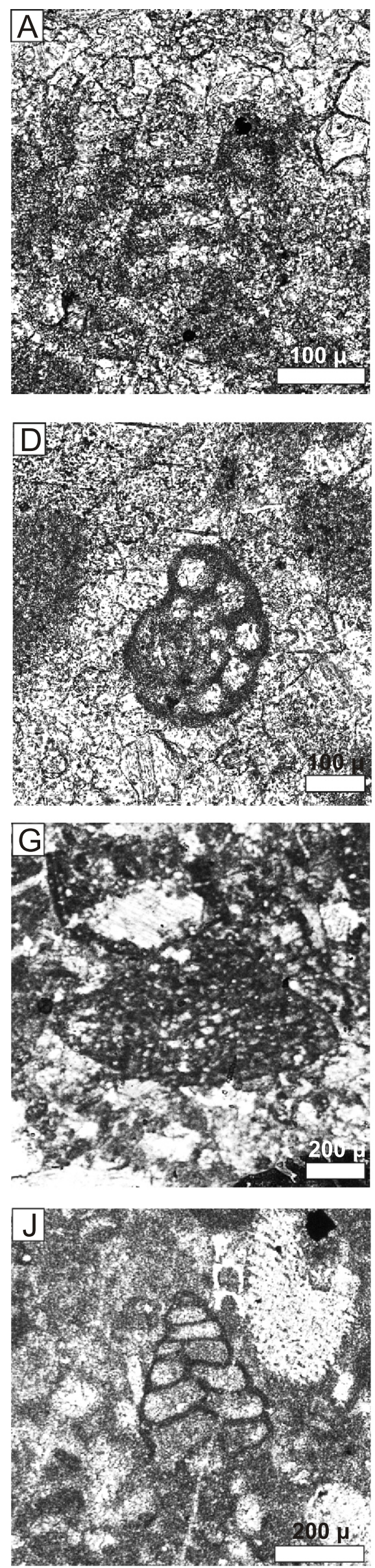
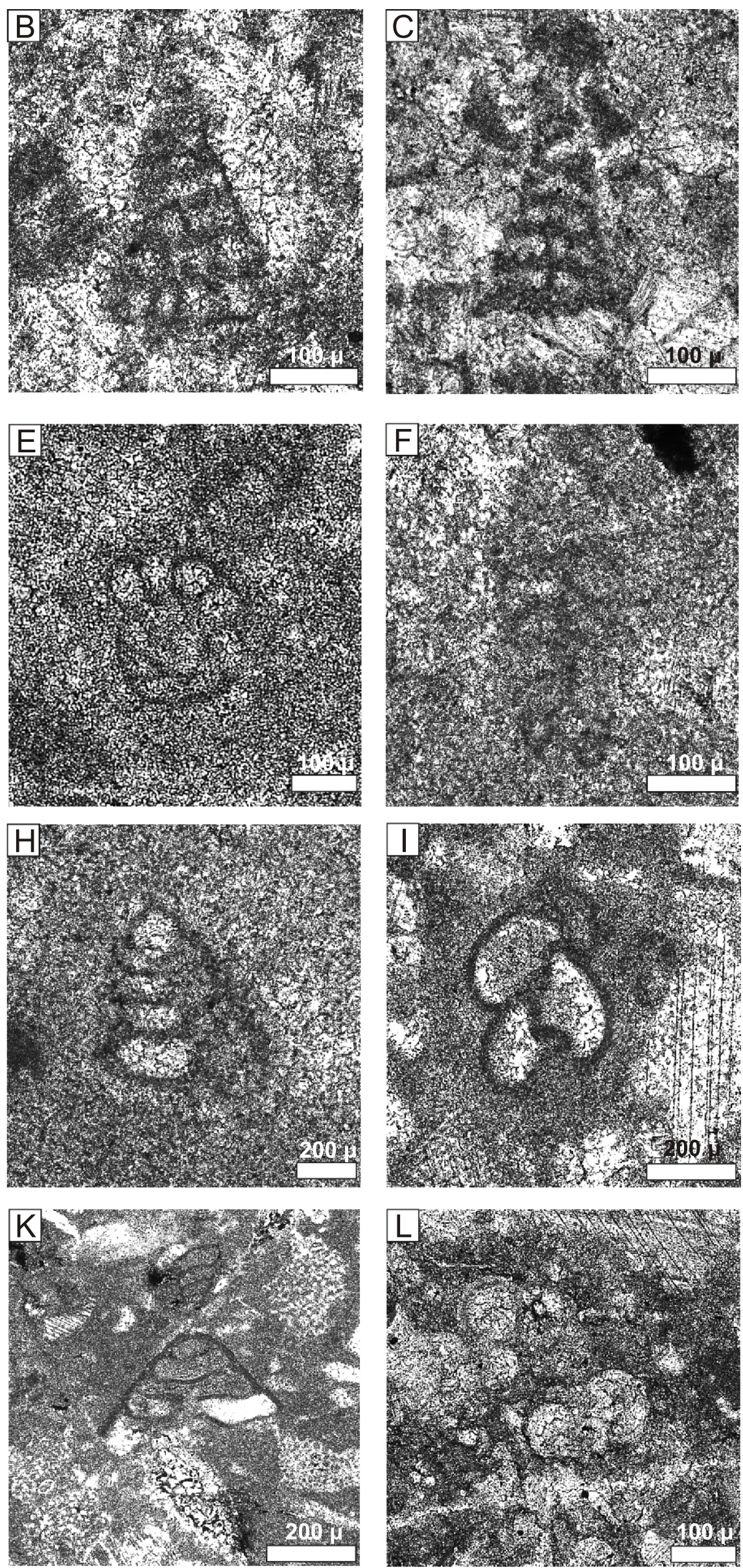


\section{DISCUSSION}

STRATIGRAPHIC POSITION OF THE ALKALINE VOLCANIC ROCKS

In the uppermost part of the Sobótka Limestone Member thin tuffitic laminae between pale micritic limestones and pinkish crinoidal limestones have been reported (Kotański and Radwański, 1959; Lefeld et al., 1985). The Tithonian age of the Sobótka Limestone Member is based on aptychi (Gasiorowski, 1962), and the brachiopod Pygope dyphia Buch (Kotański and Radwański, 1959). These authors also described calpionellids such as Calpionella alpina Lorenz and Calpionella elliptica Cadisch which determine that the stratigraphic range of the Sobótka Limestone Member is up to late Early-early Middle Berriasian (according to the calpionellid zonation of Reháková and Michalík, 1997). Hence, the first phases of volcanism began during the latest Tithonian-early Middle Berriasian (cf. Kotański and Radwański, 1959; Staniszewska and Ciborowski, 2000).

A $10 \mathrm{~m}$ thick carbonate microbreccia unit occurs above the Sobótka Limestone Member. The carbonate microbreccia comprises almost exclusively limestone clasts identical to those which form the upper parts of the Raptawicka Turnia Limestone Formation in the Polish part of the Western Tatra Mts. (Staniszewska and Ciborowski, 2000). According to our research, the youngest calpionellid identified in the oolitic and micritic limestone clasts is Calpionella elliptica Cadisch that corresponds with the Elliptica Subzone of the Calpionella Zone of the late Early-early Middle Berriasian (calpionellid zonation of Reháková and Michalík, 1997). However, the Simplex Subzone of Calpionellopsis Zone of the late Middle-early Late Berriasian is documented by very rare occurrences of ?Calpionellopsis cf. simplex (Colom) in the oolitic limestone clasts (Staniszewska and Ciborowski, 2000). Accordingly, the carbonate breccia was formed certainly after the late Middle-early Late Berriasian, thus the age of breccia formation is most likely Late Berriasian.

The volcanic rocks are overlain by the Osobitá Limestone Formation (Lefeld et al., 1985). The contact of the Osobitá Limestone Formation with the volcanic rocks has been characterized as tectonic (Lefeld, 1968; Lefeld et al., 1985); consequently, the lowest horizons of this formation are missing in places. Lefeld (1968) compiled a composite lithological profile of the Early Cretaceous of the autochthonous cover of the High-Tatric Unit of the Osobitá peak area. In the lowermost part of the Osobitá Limestone Formation he described very thin strata of dark grey pelitic globigerina-bearing limestones followed by dark and reddish organodetrital crinoidal limestones well-exposed in the old quarry in the Bobrovecká Valley. He described Palorbitolina lenticularis (Blumenbach) from these crinoidal limestones, determine the Late Barremian-Early Aptian age of the Osobitá Limestone Formation. At our studied localities, the volcanic rocks are overlain by $4-6 \mathrm{~m}$ thick reddish and dark grey organodetrital limestones with abundant crinoid fragments. The lower parts of the crinoidal limestones contain foraminifers such as Meandrospira favrei (Charollais, Brönnimann and Zaninetti), Sabaudia minuta Hofker and Montsalevia salevensis (Charollais, Brönnimann and Zaninetti) that suggest an Late Valanginian-Early Hauterivian age. We found orbitolinid foraminifers of the Palorbitolina-Mesorbitolina group at higher levels in the crinoidal limestones at localities L3 and L5 (Fig. 3). Orbitolinas of this group indicate an Late Barremian, possibly up to Early Albian, age for these levels in the crinoidal limestones.

Summing up, the previously published studies and our biostratigraphic data from strata underlying and overlying the volcanics, point to a stratigraphic range of volcanic activity from the latest Tithonian to the ?Early Valanginian. Less intense phases of volcanism are recorded as thin tuffitic laminae in the upper parts of the Tithonian to early Middle Berriasian Sobótka Limestone Member and as fragments of volcanic rock in the carbonate microbreccia. The main phase of volcanism took place during the Late Berriasian to the ?Early Valanginian. Similar breccia beds (the Walentowa Breccia Member of the Lysa Limestone Formation of Birkenmajer, 1977) are also known within Early Cretaceous deposits from several places within the Czorsztyn Succession of the Pieniny Klippen Belt (e.g., Wierzbowski and Remane, 1992). More recently, mineralogically and geochemically similar basalts and tuffs (Oszczypko et al., 2012) have been studied within Early Cretaceous strata of the Veliky Kamenets section in the eastern part of the Pieniny Klippen Belt in the Ukrainian Carpathians. The age of this volcanic event is very precisely located in the Elliptica-Simplex Subzones of the Middle and early Late Berriasian (Reháková et al., 2011). This could indicate that the overlying Upper Valanginian-Lower Hauterivian limestones do not necessary overlie the volcanics in stratigraphical continuity, with a possible stratigraphical gap at the base of the Osobitá Limestone Formation.

In the Central Western Carpathians there are similar alkaline volcanic rocks (mostly basanites) known in Early Cretaceous strata from the Tatric and (mainly) from the Fatric Unit (Hovorka and Spišiak, 1988 and references therein). Occurrences of small hyalobasanitic lava bodies or volcaniclastic units within probable Aptian deep-marine strata of the Tatric sedimentary cover are known from the Malé Karpaty Mts. (Mahel', 1986). Several hyalobasanitic lava and volcaniclastic units are described from the Barremian-Lower Aptian deposits of the Nízke Tatry Mts. (Bujnovský et al., 1981). Basanite intrusions and dykes in the Tatric basement granitoid rocks have also been reported in this area (Hovorka et al., 1982; Spišiak et al., 1991). The K/Ar age determined for these dykes (Spišiak and Balogh, 2002) is approximately $100 \mathrm{Ma}$ (Albian).

Many small lava bodies of basalt/basanite type are known in the Fatric Unit within Lower Cretaceous strata (Zorkovský, 1949; Hovorka and Sýkora, 1979; Hovorka and Spišiak, 1988). Occurrences of picrite veins in the Triassic carbonates have also been reported (Spišiak and Hovorka, 2000). The age of this volcanic activity, based on biostratigraphic and geochronological data is generally Aptian to Early Albian (K/Ar isotopic ages 106 and $116 \mathrm{Ma}$, Bujnovský et al., 1981). Small basalt exposures formed by hyalobasanitic lavas have also been described within Lower Albian marly deposits of the Drietoma or Manín Unit (Kullmanová and Vozár, 1980).

Available biostratigraphic and geochronological data indicate that the Cretaceous alkaline volcanism in the Central Western Carpathians area started during the latest Jurassic-earliest Cretaceous (at ca.140 Ma) and culminated during the Aptian and Early Albian (Hovorka and Spišiak, 1988, 1990; Spišiak et al., 2011).

\section{INFERRED VOLCANIC PROCESSES}

As described above, the first volcanic phases are recorded as thin tuffitic laminae (Kotański and Radwański, 1959; Lefeld et al., 1985) intercalated within crinoidal and pale micritic limestones of the Sobótka Limestone Member. The tuffitic laminae comprise fine ash material clearly related to the overlying volcanic rocks (Kotański and Radwański, 1959). These authors explained the origin of the tuffitic laminae by wind transport of vol- 
canic ash. With respect to the marine character of the host strata, it can be inferred that first phases of volcanic activity represented small subaqueous explosive eruptions producing fine ash material which was deposited by suspension fallout from the water column.

A second major volcanic phase is represented by small subaqueous lavas associated with abundant volcaniclastic deposits (Kotański and Radwański, 1959; Hovorka and Spišiak, 1981, 1988). Only one exposure of a $25 \mathrm{~m}$ thick lava associated with volcaniclastics has been reported on the east slope of Osobitá peak (Kotański and Radwański, 1959). Unfortunately, during our research, this locality had been overgrown by impenetrable scrub pine vegetation and so we were unable to examine it. Kotański and Radwański (1959) also identified ropy lava surface features together with welded pinkish crinoidal limestone in debris in the Suchá Valley creek. These features are characteristic of sheet-like lava flows which are common in subaqueous settings (e.g., Batiza and White, 2000). Other evidence of subaqueous lavas such as pillow and lobate lavas have not yet been found in the area studied. We assume that the basanite lava was sourced via linear feeder dykes. The composition and zoning of clinopyroxene minerals in the Cretaceous alkaline rocks of the Western Carpathians suggest similar conditions of their generation (approx. $23 \mathrm{kbar}$ and $1260^{\circ} \mathrm{C}$ ). A very low magma viscosity and suitable geotectonic conditions caused rapid magma ascent and its further development (Spišiak and Hovorka, 1997). Increased phenocryst content is also consistent with viscous lava flow. Relatively abundant amygdales in the lavas indicate elevated gas contents. The elongated shape and varied orientation of the amygdales (Fig. 8A, B) suggest flow transformation during cooling. The margins and tops of the flows were rapidly quenched and fragmented but flow cores remained viscous and cooled gradually. High effusion rates, ropy lava surface features together with steeper slopes are characteristic of sheet-like lava flows (Batiza and White, 2000). Sheet-like lava flows are commonly associated with large volumes of hyaloclastite (Batiza et al., 1984).

The volcaniclastic deposits have been regarded as hyaloclastites based on shape, grain-size composition and the character of the carbonate matrix (Hovorka and Spišiak, 1981, 1988). The hyaloclastites comprise glass-fragment rocks, while the term has broad application to any product of magma-water interaction (e.g., Fisher and Schmincke, 1984). Another common usage of the term limits hyaloclastite to glassy debris formed by essentially non-explosive processes related to rapid aqueous cooling of magma with limited or no transport of fragments (Batiza and White, 2000). Recently, the term hyaloclastite has been used for primary volcaniclastic deposits formed during effusive volcanism when extruding magma or flowing lava is chilled and fragmented from contact with water and fragments are deposited only under the influence of the continued emplacement of lava (White and Houghton, 2006). These types of hyaloclastite can be recognized at localities L3 and L4 (Figs. 1 and 6A).

Hyaloclastites observed at localities L1 and L2 in the Suchá Valley (Široký Gully; Fig. 1) show evident sedimentary features (Fig. 6B), suggesting different processes of formation, but the poor exposure makes interpretation difficult.

One possibility is that these deposits are the result of syn- or post-eruption remobilisation and reworking of autobrecciated hyaloclastites at the front or top of flow margins (e.g., McPhie et al., 1993). Hyaloclastite material is prone to remobilisation by sea-bottom currents or via gravity-driven mass flows (Lonsdale and Batiza, 1980). Hovorka and Spišiak (1988) suggested that the present distribution of volcanic rocks reflects volcanic activity at one centre (situated close to the exposure described by Kotański and Radwański, 1959), the products of volcanic activity then being reworked and transported across different distances by slumping and sliding.

Another possibility is that these deposits are a result of subaqueous eruption-fed density currents (White, 2000). Distinction of ancient subaqueous eruption-fed density current deposits from those resulting from entirely post-eruptive redistribution of particles by turbidity currents or other mass flows is difficult. Nevertheless, the unabraded margins of volcanic particles, high glass content, moderate to high vesicularity of basanite clasts suggest lava-fed density currents (White, 2000) as more probable than post-eruption reworking of in-situ hyaloclastites. Minor admixture of accidental (lithic) rock fragments also supports this interpretation. Transport and depositional processes of lava-fed density currents are controlled directly by the nature of the eruption and its interaction with the surrounding water. The moderate to high vesicularity of the basanite studied indicates increased gas content in the magma. Increased gas content in magma is a predictor of explosive volcanic activity in subaqueous settings, but if the bubbles are uniformly distributed in the magma, a vesicular magma may be erupted effusively. This leads to gas exsolution and the formation of vesicular lava flows (Head and Wilson, 2003). Fragmentation along surfaces of flowing lava may result in development of a hyaloclastite carapace (White, 2000). Fragments are formed at the surface of advancing lava flows by dynamic thermal shock, vesiculation from gas expansion or minor steam explosivity (Batiza et al., 1984), but a primary mechanism for the formation of hyaloclastite at any water depth is cooling-contraction granulation (Kokelaar, 1986). Entrainment of fragments into density currents is aided by heating of the surrounding water along the flow margins, which generates convecting steam and heated water which produces significant rising currents above advancing subaqueous lava flows. Finer particles are inferred to accumulate in suspension to feed initially vertical, low-energy, density currents which subsequently move downslope along the seafloor. The coarsest entrained particles may settle individually to form restricted fall deposits (White, 2000).

\section{PALAEOENVIRONMENT}

The Central Western Carpathians realm is characterized by generally uniform pelagic sedimentation (Plašienka, 1999; pelagic micritic limestones of the "Neocomian Facies"; e.g., Michalík and Vašíček, 1989; Michalík, 1995) during the Late Jurassic-Early Cretaceous. During this time interval, an extensional tectonic regime with several pre-orogenic rifting phases that generated subsiding basinal domains separated by submarine and/or subaerial highs prevailed in the Western Carpathian realm (e.g., Michalík et al., 1996; Michalík and Soták, 1990; Plašienka, 2003; Jurewicz, 2005). These rifting events are reconstructed indirectly from the sedimentary successions in the Western Carpathians and are the result of the break-up of the South Penninic-Vahic Ocean in the late Middle Jurassic and as the result of the break-up of the North Penninic-Magura Ocean in the Early Cretaceous. The absence of rift-related volcanism and the persistence of an extensional tectonic regime for many millions of years indicate a passive rifting mode generated by tensile deviatoric stresses within the lithosphere (Plašienka, 2003).

The strata studied were deposited in areas with an irregular submarine seafloor related to pelagic swells or submarine 
ridges most probably bordered by deep-rooted extensional normal faults as inferred by Mišík (1974). The irregular topography is documented by carbonate scarp breccias (Staniszewska and Ciborowski, 2000).

Carbonate breccia layers indicate rejuvenation of the basin floor by synsedimentary tectonics during the Early Cretaceous. The mixed composition of the redeposited limestone clasts reflects significant topography. Scattered siliciclastic detritus containing rounded quartz and feldspar grains and rare clays were most likely recycled from older Triassic-Jurassic units in the autochthonous cover of the High-Tatric Unit, perhaps even from the crystalline core of the Tatra Mts.

The presence of the oolitic limestone facies suggest an active shallow-marine environment. For instance, a similar limestone facies with ooids, peloids, bioclasts and intraclasts of ooid grainstone is known from Pacific guyots, where it forms thick units associated with basalt bodies (e.g., Jenkyns and Strasser, 1995; Jenkyns and Wilson, 1999). The clasts of oolitic limestone may have been derived from the highest part of the pelagic swell or an isolated platform.

Carbonate breccias were deposited most probably along normal faults as base-of-slope debris-apron deposits. Similar limestone breccia bodies (the Nozdrovice breccia beds; Borza et al., 1980) intercalated within Lower Cretaceous pelagic basinal strata are known from several places from the Fatric Unit of the Central Western Carpathians. The Nozdrovice breccia beds have been interpreted in terms of talus debris accumulation along active submarine fault slopes connected with submarine elevations (Michalík and Reháková, 1995). Equally, alternation of crinoidal limestone with pale micritic limestone accompanied by thin tuffitic laminae suggest an allodapic character of the Sobótka Limestone Member (cf. Staniszewska and Ciborowski, 2000). Crinoid debris and detrital material was intermittently discharged by sediment gravity flows from swell margins into a deeper environment, where it was interbedded with pelagic micritic limestones.

All these deposits and associated basic volcanics may be related to the Berriasian-Hauterivian Walentowa Phase (Plašienka, 2003), which marks further foreland-ward migration of rifting, interpreted to record the break-up of the Magura Ocean.

Recognized biocalcirudites and biocalcarenites of Early Cretaceous age in the High-Tatric Unit were regarded as Urgonian-type sediments (Passendorfer, 1922; Lefeld, 1968). The Urgonian-type sediments are a characteristic shallow-water carbonate-platform facies that accumulated along the Tethys northern shelf generally from the Barremian to the Late Albian (e.g., Michalík, 1994; Bernaus et al., 2003; Godet et al., 2010). These Urgonian-type sediments in the High-Tatric Unit are known as the Wysoka Turnia Limestone Formation (Lefeld et al., 1985). The Wysoka Turnia Limestone Formation is replaced in the Osobitá peak area by well-bedded dark grey limestones with brownish cherts of the Osobitá Limestone Formation, which has been described as a distal facies of the High-Tatric Urgonian (Lefeld, 1968; Lefeld et al., 1985). The base of the Osobitá Limestone Formation is composed of detrital crinoidal limestones which are characterized by alternations of grainstones with packstones. They comprise fragments of shallow-water organisms such as rare corals, orbitolinas, brachiopods and bivalves and abundant crinoid fragments. Several gradational sedimentary cycles have been recognized in these detrital crinoidal limestones (Lefeld, 1968). These features indicate an allodapic character of sediments which were generated by turbidity currents or by other sediment gravity flows at the slope of the Urgonian carbonate platform (cf. Michalík and Soták, 1990).

Development of the Urgonian carbonate platforms was probably caused by a temporary lowering of bathymetry by several hundred metres. In addition to the eustatic sea level drop, differential uplift was related to an extensional tectonic regime demonstrated by reactivation of normal faults, horst formation and extensional block tilting (Michalík and Soták, 1990; Michalík, 1994). Uplift and submergence of the Urgonian platform of the High-Tatric Unit occurred at different times in different places (Masse and Uchman, 1997). The Early Cretaceous alkaline volcanic activity partly coincides with development of the Urgonian carbonate platforms in the Western Carpathians (Spišiak et al., 2011). According to our microfacies and biostratigraphic investigations, submarine platforms or shallow-water swells similar to the Urgonian carbonate platform existed or began to develop during the Late Valanginian-Early Hauterivian in this zone of Tatric realm.

Accordingly, the sedimentary record of under- and overlying carbonate rocks suggest redeposition of shallow-water facies (e.g., clasts of ooidal limestone in the carbonate breccia or coral fragments in the Osobitá Limestone Formation) into a deeper depositional environment. The shallow-water facies pass laterally into pelagic deposits of the same age, but unambiguous indicators of palaeodepth of subaqueous volcanism have not been previously described. The absence of direct sedimentological or ecological depth criteria causes the interpretation to be poorly constrained and estimation of the paleodepth of these resedimented deposits is problematic.

If the nature of volcanic activity is taken into consideration, the depth of magmatic explosivity depends largely on magma composition and juvenile volatile content (Kokelaar, 1986). A common assumption about subaqueous volcanic eruptions is that if the pressure of the overlying water is sufficient to suppress juvenile gas exsolution than magmatic disruption and pyroclastic activity does not occur, this being confined to shallow depths (Batiza and White, 2000). This is referred to as volatile fragmentation depth (Fisher and Schmincke, 1984). This depth is generally recognized to be about 200 up to $1000 \mathrm{~m}$ for alkaline magmas (Kokelaar, 1986). However, certain circumstances (e.g., high content of $\mathrm{CO}_{2}$ in alkaline basaltic magmas) can lead to magma disruption and explosive activity at great water depths (Head and Wilson, 2003).

\section{GEODYNAMIC REMARKS}

The general framework of the Mesozoic mafic alkaline volcanism in Central Europe and the geodynamic background of the Early Cretaceous alkaline volcanism in the Western Carpathians have been discussed and reviewed in the paper by Spišiak et al. (2011).

Suites of alkali basalts and their differentiates (basanites, nephelinites) are commonly found in intra-plate (Wilson, 2007) anorogenic tectonic enviroments (Wilson and Downes, 1991; Bailey and Wooley, 1999). They are commonly related to extensional tectonic regimes and occur in both oceanic and continental areas, but their presence becomes increasingly important in areas with continental lithosphere. A possible source for the Cretaceous and Cenozoic alkaline basaltic volcanism in the Western and Central Europe is an extensive sheet-like subcontinental mantle reservoir designated as the Common Mantle Reservoir (see Lustrino and Wilson, 2007). These authors also summarized published opinions and conceptual models that at- 
tempt to explain the origin of Cenozoic basalts in the circum-Mediterranean area. Suggestions range from the deep mantle plume hypothesis, through "thin spot", "mantle fingers", plume channeling, passive rifting and mantle upwelling models, up to mantle lithospheric decompression melting due to lithospheric stretching. The same applies to the Cretaceous alkali basalts around Europe. All models are based on variations of rising mantle plume material as a source for the Cretaceous alkaline basaltic volcanism, but do not take into consideration the tectonic style of rifting that governed the opening of several oceanic realms of the Alpine Tethys (Penninicum) (see discussion by Spišiak et al., 2011 and references therein).

The geological record from the Alpine-Carpathian orogen indicates a passive, volcanic-poor rifting mode during the Jurassic and Early Cretaceous. Rifting and continental breakup were consequences of tensional stresses in the lithosphere located in the foreland of the developed orogenic wedge (e.g., Michalík et al., 1996; Plašienka, 1999, 2003; Froitzheim et al., 2008). Alkaline basaltic volcanism occurred on passive continental margins of the Penninic rifts, being generated by low-degree partial melting of the sub-continental mantle lithosphere on the periphery of asthenospheric upwelling confined to slow-spreading ridges of the Alpine Tethys. The magma ascent and piercing of the overlying lithosphere was enhanced by the general extensional tectonic regime and considerable lithospheric thinning as a result of preceding and coeval rifting events. Alkaline volcanism generally postdated the main rifting, hence it appears to be a product, and not the cause, of rifting (Spišiak et al., 2011). Accordingly, these authors support a non-plume origin for the Cretaceous alkaline volcanism in the Alpine-Carpathian-Pannonian realm.

\section{CONCLUSIONS}

Five composite lithological sections across uppermost Jurassic-lowermost Cretaceous carbonate strata sandwiching volcanic rocks have been studied. (1) Carbonate microbreccia that consists almost exclusively of limestone clasts containing calpionellids occurs immediately below the volcanic rocks. The youngest identified calpionellid in the limestone clasts is Calpionella elliptica Cadisch, which corresponds to the Elliptica Subzone of the Calpionella Zone of the late Early-early Middle Berriasian. (2) Carbonate microbreccia layers indicate distinct rejuvenation of the basin floor by synsedimentary tectonics during the Early Cretaceous. Carbonate microbreccia originated most probably along normal faults as base-of-slope debris-apron deposits. The mixed composition of the redeposited limestone clasts in the carbonate microbreccia point to the existence of significant topography differences with shallow-water swells or submarine ridges. (3) Volcanic rocks are overlain by thin strata of dark grey and reddish crinoidal limestones that form the base of the Osobitá Limestone Formation. The lowermost levels of these crinoidal limestones are characterized by alternations of grainstone and packstone bearing newly described foraminifers such as Meandrospira favrei (Charollais, Brönnimann and Zaninetti), Sabaudia minuta Hofker and Montsalevia salevensis (Charollais, Brönnimann and Zaninetti) which indicate an Late Valanginian-Early Hauterivian age for these levels. Higher levels of crinoidal limestone consist of packstone/wackstone with orbitolinid foraminifers of the Palorbitolina-Mesorbitolina group, that suggest a wider stratigraphic range from the Late Barremian up to an Early Albian age. (4) Our new and previously published biostratigraphic data from underlying and overlying beds sandwiching the volcanic rocks indicate a stratigraphic range for the volcanic activity from the latest Tithonian to the ?Early Valanginian. The first minor phases of volcanism are recorded as thin tuffitic laminae within the upper parts of the Tithonian-early Middle Berriasian Sobótka Limestone Member (Kotański and Radwański, 1959; Lefeld et al., 1985) and also as volcanic fragments in carbonate microbreccias which immediately underlie the volcanic rocks. The major phase(s) of volcanism took place after the Middle Berriasian (cf. Staniszewska and Ciborowski, 2000) during the Late Berriasian to the ?Early Valanginian. This is recorded by small parts of subaqueous lavas associated with abundant volcaniclastic deposits (cf. Kotański and Radwański, 1959; Hovorka and Spišiak, 1981, 1988). (5) Textural and sedimentary features of the volcaniclastic rocks suggest origin via either syn- or post-eruption reworking and resedimentation or lava-fed eruption density currents. Taking into account the unabraded margins of the volcanic particles, the high glass content, moderate to high vesicularity of the basanite clasts and a minor admixture of accidental (lithic) rock fragments we suggest lava-fed density currents as more likely.

Acknowledgements. The authors wish to thank I. Bucur, A. Wierzbowski and two anonymous reviewers for their constructive criticism. We are indebted to editors T. Peryt and J. Grabowski for their thorough editorial work and patience and J. Zalasiewicz for improving the English. Our thanks go also to our colleagues from the Department of Geology and Palaentology for helpful comments. This study was supported by scientific projects VEGA $1 / 0274 / 10$ and 2/0042/12, financial support from these grants is gratefully acknowledged.

\section{REFERENCES}

Bailey D.K., Wooley A.R. (1999) Episodic rift magmatism: the need for a new paradigm in global dynamics. GeoLines, 9: 15-20.

Batiza R., White J.D.L. (2000) Submarine lavas and hyaloclastite. In: Encyclopedia of Volcanoes (ed. H. Siggurdson): 361-381. Academic Press.

Batiza R., Fornari D.L., Vanko D.A., Lonsdale P. (1984) Craters, calderas and hyaloclastites on young Pacific seamounts. Journal of Geophysical Research, 89 (B10): 8371-8390.
Bernaus M.J., Arnaud-Vanneau A., Caus E. (2003) Carbonate platform sequence stratigraphy in a rapidly subsiding area: the Late Barremian-Early Aptian of the Organyà basin, Spanish Pyrenees. Sedimentary Geology, 159: 177-201.

Birkenmajer K. (1977) Jurassic and Cretaceous lithostratigraphic units of the Pieniny Klippen Belt, Carpathians, Poland. Studia Geologica Polonica, 45: 1-158.

Borza K., Gašparíková V., Michalík J., Vašíček Z. (1980) Upper Jurassic-Lower Cretaceous sequence of the Križna Nappe 
(Fatric) in the Stražovce section, Strážovské Vrchy Mts. (Western Carpathians). Geologica Carpathica, 31: 541-562.

Bujnovský A., Kantor J., Vozár J. (1981) Radiometric dating of Mesozoic basic eruptive rocks of the Križna Nappe in the NW part of the Low Tatra Mts. Geologický Zborník Geologica Carpathica, 32: 221-230.

Dunham R.J. (1962) Classification of carbonate rocks according to a depositional texture. American Association of Petroleum Geologists, Memoir, 1: 108-121.

Fisher R.V. (1961) Proposed classification of volcaniclastic sediments and rocks. GSA Bulletin, 72: 1395-1408.

Fisher R.V., Schmincke H.U. (1984) Pyroclastic Rocks. Springer-Verlag, Berlin.

Froitzheim N., Plašienka D., Schuster R. (2008) Alpine tectonics of the Alps and Western Carpathians. In: The geology of Central Europe. Volume 2: Mesozoic and Cenozoic (ed. T. McCann): 1141-1232. Geol. Soc. Publ. House, London.

Gasiorowski S.M. (1962) Aptychi from the Dogger, Malm and Neocomian in the Western Carpathians, and their stratigraphical value. Studia Geologica Polonica, 10: 1-151.

Godet A., Föllmi B.K., Bodin S., Kaenel de E., Matera V., Adatte T. (2010) Stratigraphic, sedimentological and palaeoenviromental contraints on the rise of the Urgonian platform in the western Swiss Jura. Sedimentology, 57: 1088-1125.

Head W.J., Wilson L. (2003) Deep submarine pyroclastic eruptions: theory and predicted landforms and deposits. Journal of Volcanology and Geotermal Research, 121:155-193.

Hovorka D., Spišiak J. (1981) Hyalobasanites (Limburgites) of Osobitá peak in the Tatra Mts. (in Slovak with English summary). In: Palaeovolcanism in the Western Carpathians (eds. S Bajaník and D. Hovorka): 145-156. Geol. ústav D. Štúra, Bratislava.

Hovorka D., Spišiak J. (1988) Mesozoic volcanism of the Western Carpathians (in Slovak with English summary). Veda, Bratislava.

Hovorka D., Spišiak J. (1990) Lithostratigraphic division of the products of Mesozoic volcanism in the Western Carpathians (in Slovak with English summary). Geologické práce, Správy, $\mathbf{9 1}$ 75-89.

Hovorka D., Spišiak J. (1993) Mesozoic volcanic activity in the Western Carpathian segment of the Tethyan Belt. Diversities in space and time. Jahrbuch der Geologischen Bundesanstalt, 136: 769-782.

Hovorka D., Sýkora M. (1979) Neocomian basic volcanic in the Križna Nappe of the Vel'ká Fatra Mts. (West Carpathians) (in Slovak with English summary). Časopis pro mineralogii a geologii, 24: 371-383.

Hovorka D., Chovan M., Michalek J. (1982) Olivine kersantite in granodiorites near Dúbrava (Nízke Tatry Mts.) (in Slovak with English summary). Mineralia Slovaca, 14: 85-90.

Hovorka D., Dostál J., Spišiak J. (1999) Geochemistry of the Cretaceous alkali basaltic rocks of the central part of the Western Carpathians (Slovakia). Kryštalinikum, 25: 37-48.

Ivan P., Hovorka D., Méres Š. (1999) Riftogenic volcanism in the Western Carpathian geological history: a review. GeoLines, 9: $41-47$.

Jenkyns H.C., Strasser A. (1995) Lower Cretaceous oolites from the Mid-Pacific Mountains (Resolution Guyot, site 866). Proceedings of the Ocean Drilling Program, Scientific Results, 143: $111-118$.

Jenkyns H.C., Wilson P.A. (1999) Stratigraphy, paleoceanography and evolution of Cretaceous Pacific guyots: relict from a greenhouse Earth. American Journal of Science, 299: 341-392.

Jurewicz E. (2005) Geodynamic evolution of the Tatra Mts. and the Pieniny Klippen Belt (Western Carpathians): problems and comments. Acta Geologica Polonica, 55: 295-338.
Kokelaar P. (1986) Magma-water interactions in subaqueous and emergent basaltic volcanism. Bulletin of Volcanology, 48: 275-289.

Kotański Z., Radwański A. (1959) High-Tatric Tithonian in the Osobita region, its fauna with Pygope diphya and products of the volcanoes, Western Tatra Mts) (in Polish with English summary). Acta Geologica Polonica, 9: 519-534.

Krajewski K. (1981) Pelagic stromatolites from High Tatric Albian limestones in the Tatra Mts. (in Polish with English summary). Kwartalnik Geologiczny, 25 (4): 731-759.

Kreutz S. (1909) Limburgite rocks in the Tatra Mts. (in Polish) Kosmos, Ser. B, 34: 625-631.

Kreutz S. (1913) About Limburgite rocks in the Tatra Mts. (in Polish with German summary). Rozprawy Wydziału MatematycznoPrzyrodniczego PAU, seria A, 53: 57-78.

Kullmanová A., Vozár J. (1980) Hyaloclastic lava in a marly sequence of Lower Albian age in the middle Váh valley, Western Slovakia (in Slovak with English summary). Mineralia Slovaca, 12: $53-62$.

Lefeld J. (1968) Stratigraphy and palaeogeography of the High-Tatric lower Cretaceous in the Tatra Mountains (in Polish with English summary). Studia Geologica Polonica, 24: 7-115.

Lefeld J., Gaździcki A., Iwanow A., Krajewski K., Wójcik K. (1985) Jurassic and Cretaceous lithostratigraphic units of the Tatra Mountains. Studia Geologica Polonica, 84: 1-93.

Lonsdale P., Batiza R. (1980) Hyaloclastite and lava flows on young seamounts examined with a submersible. GSA Bulletin, 91: $545-554$.

Lustrino M., Wilson M. (2007) The circum-Mediterranean anorogenic Cenozoic igneous province. Earth-Science Reviews, 81: 1-65.

Mahel' M. (1986) New knowledge about crystalline basement and its Mesozoic cover in the Malé Karpaty Mts. and Považský Inovec Mts. (in Slovak). Manuscript Archive GúDŠ (no. 58287), Bratislava.

Masse J.P., Uchman A. (1997) New biostratigraphic data on the Early Cretaceous platform carbonates of the Tatra Mountains, Western Carpathians, Poland. Cretaceous Research, 18: 713-729.

McPhie J., Doyle M., Allen R. (1993) Volcanic textures: a guide to the interpretation of textures in volcanic rocks. Hobart, Codes Key Centre, University of Tasmania.

Michalík J. (1994) Lower Cretaceous carbonate platform facies, Western Carpathians. Palaeogeography, Palaeoclimatology, Palaeoecology, 111: 263-277.

Michalík J. (1995) Lower Cretaceous stratigraphy, facies, faunas and Tethyan/Boreal influences in the Western Carpathians. Cretaceous Research, 16: 299-310.

Michalík J., Reháková D. (1995) Sedimentary records of Early Cretaceous tectonic activity in the Alpine-Carpathian Region. Slovak Geological Magazine, 2: 159-164.

Michalík J., Soták J. (1990) Lower Cretaceous shallow marine buildups in the Western Carpathians and their relationship to pelagic facies. Cretaceous Research, 11: 211-227.

Michalík J., Vašiček Z. (1989) Lower Cretaceous stratigraphy and paleogeography of the Czechoslovakian Western Carpathians. In: Cretaceous of the Western Tethys (ed. J. Wiedmann): 505-523. Proceedings of the 3rd International Cretaceous Symposium, Tübingen 1987; Schweizerbart, Stuttgart.

Michalík J., Reháková D., Jablonský J. (1996) Geodynamic setting of fluxoturbidites in West Carpathian Upper Jurassic and Lower Cretaceous sedimentary basins. Slovak Geological Magazine, 3-4: 325-329.

Mikuš T., Spišiak J., Sýkora M., Demko R. (2006) Chemical composition of spinels from Mesozoic alkali basalts: implications for sources of detrital spinels in flysch sediments. Geologica Carpathica, 57: 447-460. 
Mišík M. (1974) Paleogeographic outline of the Tithonian in the Czechoslovakian Carpathians. Acta Geologica Polonica, 24: 485-503.

Nemčok J., Bezák V., Janák M., Kahan Š., Ryka W., Kohút M., Lehotský I., Wieczorek J., Zelman J., Mello J., Halouzka R., Raczkowski W., Kotanski Z., Reichwalder P. (1993) Geological map of Tatra Mts. 1:50 000. State Geological Institute of Dionýz Štúr, Bratislava.

Oszczypko N., Salata D., Krobicki M. (2012) Early Cretaceous intra-plate volcanism in the Pieniny Klippen Belt - a case study of the Velykyi Kamenets'/Vilkhivchyk (Ukraine) and the Biala Woda (Poland) sections. Geological Quarterly, 56 (4): 629-648.

Passendorfer E. (1922) On the Urgonian of the Tatra Mts. (in Polish). Sprawozdania Państwowego Instytutu Geologicznego, 2: 601-603.

Plašienka D. (1999) Tectochronology and paleotectonic model of the Jurassic-Cretaceous evolution of the Central Western Carpathians (in Slovak with English summary). Veda, Bratislava.

Plašienka D. (2003) Dynamics of Mesozoic pre-orogenic rifting in the Western Carpathians. Mitteilungen der Österreichischen Geologischen Gesellschaft, 94: 79-98.

Rabowski F. (1933) Observations geologiques dans le group de l'Osobita, Tatra (in Polish). Sprawozdania Państwowego Instytutu Geologicznego, 7: 379-387.

Reháková D., Michalík J. (1997) Evolution and distribution of calpionellids - the most characteristic constituents of Lower Cretaceous Tethyan microplankton. Cretaceous Research, 18: 493-504.

Reháková D., Matyja A.B., Wierzbowski A., Shlögl J., Krobicki M., Barski M. (2011) Stratigraphy and microfacies of the Jurassic and lowermost Cretaceous of the Veliky Kamenets section (Pieniny Klippen Belt, Carpathians, Western Ukraine). Volumina Jurassica, 9: 61-104.

Spišiak J., Balogh K. (2002) Mesozoic alkali lamprophyres in Variscan granitoids of Malé Karpaty and Nízke Tatry mountains - geochronology and geochemistry. Geologica Carpathica, 53: 295-301.
Spišiak J., Hovorka D. (1997) Petrology of Western Carpathians Cretaceous primitive alkaline volcanics. Geologica Carpathica, 48: 113-121.

Spišiak J., Hovorka D. (2000) Picrite rocks in the vicinity of Banská Bystrica (Krížna unit, Western Carpathians). Slovak Geological Magazine, 6: 419-429.

Spišiak J., Arvensis M., Linkešová M., Pitoňák P., Caňo F. (1991) Basanite dyke in granitoids near Dúbrava, Nízke Tatry Mts., Central Slovakia. Mineralia Slovaca, 23: 339-345.

Spišiak J., Plašienka D., Bučová J., Mikuš T., Uher P. (2011) Petrology and palaeotectonic setting of Cretaceous alkaline basaltic volcanism in the Pieniny Klippen Belt (Western Carpathians, Slovakia). Geological Quarterly, 55 (1): 27-48.

Staniszewska A., Ciborowski T. (2000) Lower Cretaceous breccia from autochthonous High-Tatric Succession in Western Tatra Mts (southern Poland) (in Polish with English summary). Przegląd Geologiczny, 48: 246-250.

Uhlig V. (1899) Die Geologie des Tatragebirges, II. Tektonik des Tatragebirges, III. Geologische Gesicht des Tatragebirges, IV. Beiträ zur Oberflächengeologie. Denkschriften der kaiserlichen Akademie der Wissenschaften mathematisch-naturwissenschaftliche Klasse, Wien, 68: 43-140.

White J.D.L. (2000) Subaqueous eruption-fed density currents and their deposits. Precambrian Research, 101: 87-109.

White J.D.L., Houghton B.F. (2006) Primary volcaniclastic rocks. Geology, 34: 677-680.

Wilson M. (2007) Igneous Petrogenesis. Springer, Dordrecht.

Wilson M., Downes H. (1991) Tertiary-Quarternary extension-related alkaline magmatism in Western and Central Europe. Journal of Petrology, 32: 811-849.

Wierzbowski A., Remane J. (1993) The ammonite and calpionellid stratigraphy of the Berriasian and lowermost Valanginian in the Pieniny Klippen Belt (Carpathians, Poland). Eclogae Geologicae Helvetiae, 85: 871-891.

Zorkovský V. (1949) Basic eruptives in the Mesozoic of Western and Central Slovakia (in Slovak). Práce Štátneho Geologického Ústavu, 26: 1-44. 